\title{
Oxygen-Controlled Seed Layer in DC Sputter-Deposited ZnO:Al Substrate for Si Thin-Film Solar Cells
}

\author{
Seung-Yoon Lee, Taehyun Hwang, Woojin Lee, Sangheon Lee, Hongsik Choi, Seh-Won Ahn, Heon-Min Lee, \\ and Byungwoo Park
}

\begin{abstract}
Oxygen-controlled seed layer in Al-doped $\mathrm{ZnO}$ (ZnO:Al) thin films deposited by the industrially compatible dynamic dc magnetron sputter results in both enhanced electron mobilities and appropriate etched morphologies for the Si thin-film solar cells. At the relatively low deposition temperature of $300{ }^{\circ} \mathrm{C}$, optimized ZnO:Al film grown on the seed layer has the carrier mobility of $45 \mathrm{~cm}^{2} / \mathrm{V} \cdot \mathrm{s}$ and proper postetching morphology with around 1-2- $\mu \mathrm{m}$ crater size. Reduced angular distribution of the (002) grains analyzed by the diffraction rocking curve is shown as the key structural feature for the improved carrier mobility. Finally, the performance of the microcrystalline Si solar cell on the developed $\mathrm{ZnO}$ :Al substrate shows high-efficiency potential of the tandem solar cell adapting this transparent conductive oxide substrate.
\end{abstract}

Index Terms-a-Si-based thin-film solar cells, Al-doped $\mathrm{ZnO}$, sputtering, transparent conducting oxide.

\section{INTRODUCTION}

A LUMINUM-DOPED zinc oxide ( $\mathrm{ZnO} \mathrm{O}$ Al) has had significant roles in Si thin-film solar cells [1]-[7]. For the highefficiency Si thin-film solar cell, $\mathrm{ZnO}$ :Al front transparent conductive oxide (TCO) should have high transparency throughout the wide optical spectrum from visible to near-infrared (NIR) region, sheet resistance of $\sim 10 \Omega / \square$ (depending on the module design), and proper postetching surface morphology of uniformly distributed craters with 1-2- $\mu \mathrm{m}$ lateral size to scatter and trap the incident light into the $\mathrm{Si}$ absorber layers. Electron mobility is an important characteristic to fulfill the high transparency and low sheet resistance simultaneously [2], [8], [9], and deposition and etching processes should be precisely controlled to obtain the multifunctional materials properly [2], [5], [10]-[14].

One of the most serious issues for the application of the $\mathrm{ZnO}: \mathrm{Al}$ front $\mathrm{TCO}$ into the practical manufacturing process is

Manuscript received October 3, 2014; revised November 11, 2014; accepted November 20, 2014. Date of publication December 18, 2014; date of current version February 18, 2015. This work was supported by the National Research Foundation of Korea: 2013R1A1A2065793 and 2010-0029065.

S.-Y. Lee is with the Department of Materials Science and Engineering, Seoul National University, Seoul 151-744, Korea, and also with LG Electronics Advanced Research Institute, Seoul 137-724, Korea (e-mail: sylee101@snu.ac.kr).

T. Hwang, W. Lee, S. Lee, H. Choi, and B. Park are with the Department of materials Science and Engineering, Seoul National University, Seoul 151-744, Korea (e-mail: cimbelius@snu.ac.kr; ggongchi@snu.ac.kr; diadee@snu.ac.kr; rookies1@snu.ac.kr; byungwoo@snu.ac.kr).

S.-W. Ahn and H.-M. Lee are with LG Electronics Advanced Research Institute, Seoul 137-724, Korea (e-mail: sehwon.ahn@lge.com; ain.lee@lge.com).

Color versions of one or more of the figures in this paper are available online at http://ieeexplore.ieee.org.

Digital Object Identifier 10.1109/JPHOTOV.2014.2376052 its high deposition temperature. Most of the high-performance $\mathrm{ZnO}: \mathrm{Al}$ films have been obtained in the substrate temperature of $350^{\circ} \mathrm{C}$ or higher, which is not easy to implement to industrial in-line sputtering system [15], [16], [24] with the large substrate size over $1 \mathrm{~m}^{2}$. Very special and tricky heat management technologies should be adapted to overcome many issues occurred over $350^{\circ} \mathrm{C}$.

One tried method to acquire better $\mathrm{ZnO}: \mathrm{Al}$ thin film at lower deposition temperature is a seed or buffer-layer scheme to enhance both the crystallinity and the electrical properties of the overgrown $\mathrm{ZnO}$ :Al film [17]-[20]. In our previous work at LG Electronics, it has been shown that predeposition of $\mathrm{ZnO}: \mathrm{Al}$ seed layer with extra oxygen can result in the improved crystallinity of overgrown $\mathrm{ZnO}: \mathrm{Al}$ bulk layer and thereby reduced resistivity [20]. The oxygen-controlled $\mathrm{ZnO}: \mathrm{Al}$ seed layer has an advantage compared with other seed layer schemes [17]-[19] in that it does not increase the process costs or manufacturing steps.

In this paper, deposition of $\mathrm{ZnO}: \mathrm{Al}$ thin film with oxygencontrolled seed layer using the dynamic dc magnetron sputtering system was adjusted to obtain superior carrier mobility of $45 \mathrm{~cm}^{2} / \mathrm{V} \cdot \mathrm{s}$ at relatively low deposition temperature of $300^{\circ} \mathrm{C}$. The reduced angular distribution of the (002) preferred grains is suggested as the main origin of the improved carrier mobility. In addition, microstructural features for the appropriate postetching morphology are also discussed. Finally, the improved current density and higher efficiency of the Si thin-film solar cell were obtained by adopting the optimized $\mathrm{ZnO}: \mathrm{Al}$ substrate with oxygen-controlled seed layer.

\section{EXPERIMENTAL PROCEDURE}

The ZnO:Al films were deposited on Corning 1737 glass by a dynamic dc magnetron sputtering system equipped with a moving magnet using $\mathrm{ZnO}: \mathrm{Al}_{2} \mathrm{O}_{3}$ targets having $1.0 \mathrm{wt} \% \mathrm{Al}_{2} \mathrm{O}_{3}$ in the deposition temperature of $300{ }^{\circ} \mathrm{C}$. Deposition was performed in a dynamic deposition mode, where moving magnet bar is located in a local position of the target in a certain moment, and deposition occurs in the position just beneath the magnet. The deposition process mode is similar to that of the industrial in-line sputter system. The films were deposited by a two-step growth method [20] with a seed layer and a bulk layer. With the 9:1 ratio of $\mathrm{Ar}: \mathrm{O}_{2}$ for the seed layer, the optimum thickness of the seed layer was $\sim 40 \mathrm{~nm}$, which was previously shown appropriate for the improved electrical conductivity of the overgrown 
bulk layer and superior optical haze after wet etching [20]. In addition, the effect of deposition pressure from 0.5 to $0.2 \mathrm{~Pa}$ was also investigated in this experiment.

The deposited thin films were analyzed by X-ray diffraction (XRD: Rigaku D/MAX-IIIC) both in the $\theta-2 \theta$ and rockingcurve modes. The electrical resistivity, mobility, and carrier concentration of the films were measured by a four-point probe and a Hall measurement system (HL5500PC: BIO-RAD). The thickness of the deposited $\mathrm{ZnO}: \mathrm{Al}$ film was examined by measuring a spectroscopic ellipsometry (M2000-U) with parameters following the Tauc-Lorentz model [21].

To obtain a light-scattering rough surface, wet etching was carried out with diluted hydrochloric-acid-based aqueous solution. Etching time was adjusted to obtain proper sheet resistance of $8-10 \Omega / \square$ for the application to the $a$-Si:H based thin-film solar cell. The postetching surface morphology was observed by scanning electron microscopy (SEM: JEOL JSM-6700F), and the root-mean-square (RMS) values of surface roughness was deduced by atomic force microscopy (AFM: Nanoscope IIIa, Digital Instrument). Transmittance (T), reflectance $(R)$, and the absorptance (A) calculated by the formula $A=100 \%-T-R$ was obtained in the range from 350 to $1100 \mathrm{~nm}$ by spectrophotometer (Cary 5000, Varian), and haze values were evaluated with the ratio of the diffused transmittance over the total integrated transmittance.

The optimized $\mathrm{ZnO}: \mathrm{Al}$ film was adopted as a front TCO substrate for a single-junction microcrystalline $\mathrm{Si}(\mu \mathrm{c}-\mathrm{Si}: \mathrm{H})$ thinfilm p-i-n solar cell prepared by plasma-enhanced chemical vapor deposition. The thickness of the $i$-layer was around $2.5 \mu \mathrm{m}$, and sputtered $\mathrm{ZnO}: \mathrm{Al} / \mathrm{Ag} / \mathrm{Al}$ stack was used as a back reflecting electrode. As a reference, commercial $\mathrm{SnO}_{2}: \mathrm{F}$ substrate was also used as a front TCO. Details of silicon deposition and cell preparation are described elsewhere [22]. Light $J-V$ characterization of the solar cells was carried out using a solar simulator (Wacom) at standard test conditions (AM 1.5, $100 \mathrm{~mW} / \mathrm{cm}^{2}$ at $25^{\circ} \mathrm{C}$ ). Finally, the enhanced solar cell efficiency was analyzed by external quantum efficiency (EQE) measurement by spectral response analyzer (Bunko Keiki).

\section{RESULTS AND DISCUSSION}

\section{A. Improvement of the Carrier Mobility}

The mobility of the $\mathrm{ZnO}: \mathrm{Al}$ thin film is one of the most important properties governing the electrical and optical losses for the solar cell [1], [2], [8]. Fig. 1 shows electrical resistivity, mobility, and carrier concentration of $\mathrm{ZnO}: \mathrm{Al}$ thin films in terms of deposition pressure and with/without the seed layer. The resistivity of the $\mathrm{ZnO}: \mathrm{Al}$ thin film decreased with the decreased deposition pressure from 0.5 to $0.2 \mathrm{~Pa}$, due to the increased mobility. In each deposition pressure, the resistivity of the $\mathrm{ZnO}: \mathrm{Al}$ thin film further decreased when the seed layer was included due to the increased mobility. The carrier concentration of the films showed almost similar values in the range of 4.5 to $5.0 \times 10^{20} \mathrm{~cm}^{-3}$. Eventually, the highest mobility of $45.0 \mathrm{~cm}^{2} / \mathrm{V}$.s was obtained at the deposition pressure of $0.2 \mathrm{~Pa}$ with the seed layer. This magnitude is nearly the upper limit of the mobility in the doped polycrystalline $\mathrm{ZnO}$ thin film with that

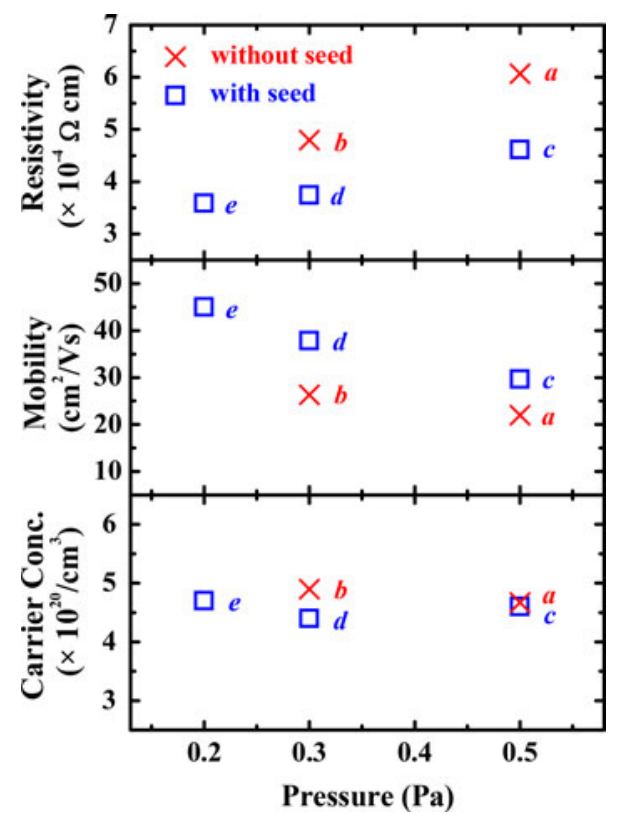

Fig. 1. Resistivity, mobility, and carrier concentration of $\mathrm{ZnO}: \mathrm{Al}$ thin films, in terms of deposition pressure, and with/without oxygen controlled seed layer. Samples $\boldsymbol{a}$ and $\boldsymbol{b}$ are thin films without the seed layer, and $\boldsymbol{c}-\boldsymbol{e}$ are those with the seed layer.

specific carrier concentration [23]. It is remarkable because such a high mobility of the $\mathrm{ZnO}: \mathrm{Al}$ film has been reported almost at the deposition temperature of $350{ }^{\circ} \mathrm{C}$ or higher in in-line dc or middle-frequency magnetron sputtering deposition [10].

\section{B. Nanostructural Analysis}

In order to systematically investigate the structural change with the deposition condition and the seed-layer adoption, XRD was performed with two different scan methods: the $\theta-2 \theta$ scan and rocking curve by $\omega$ scan.

Fig. 2(a) shows the XRD results by the $\theta-2 \theta$ scan. The films with seed layer had nearly perfect (002) preferred orientation, while the films without seed layer had mixed grains of (002) and (101) planes. In general, the $\mathrm{ZnO}: \mathrm{Al}$ film deposited by statictype RF sputter or dc sputter with enough high temperature had (002) preferred orientation [19], [25], [28]. However, in this study using the dynamic sputtering system, the deposition process is interrupted periodically due to the magnet movement, which possibly inhibit the evolution of (002) preferred grain structures. On the other hand, once the (002) orientation of the initial seed texture is formed, the growth is less affected by the deposition process [19], [25]. Therefore, it can be inferred that the oxygen-controlled seed layer provided the (002) textured platform for the growth of bulk layer.

Diffraction rocking curves by $\omega$ scan in Fig. 2(b) show higher peak intensity and narrower full-width at half-maximum (FWHM) as deposition pressure decreased (with the seed layer). The narrower FWHM of the $\omega$ peak $\left(\mathrm{FWHM}_{\omega}\right)$ means that the angular distribution of the (002) grains becomes smaller [8], [19], [25], that is, the film has more vertically aligned (002) grains. As oxygen-controlled seed layer provides the (002) textured platform, it is reasonable that the overgrown film has more 


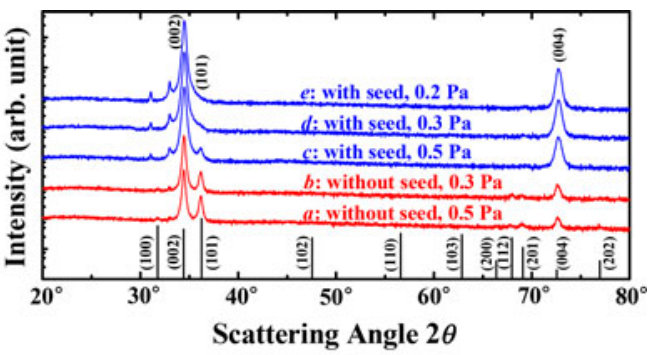

(a)

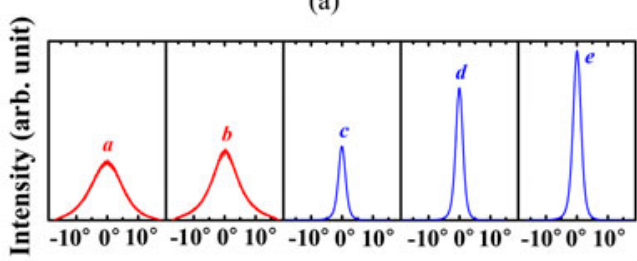

(002) Rocking Angle $\omega$

(b)

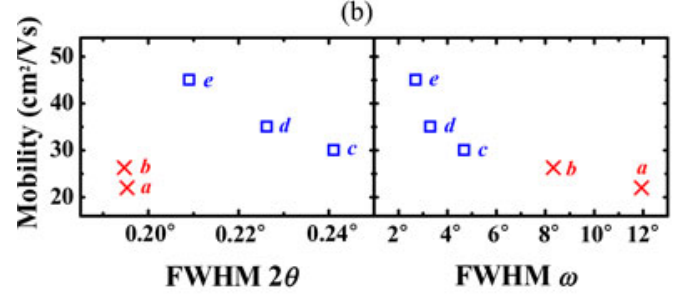

(c)

Fig. 2. XRD with (a) $\theta-2 \theta$ scan and (b) $\omega$ scan. (c) Mobility in terms of the FWHM from (a) and (b).

TABLE I

Vertical GRain Size Estimated by the $\theta-2 \theta$ DifFraction

\begin{tabular}{lccccc}
\hline \hline Sample & $\mathrm{a}$ & $\mathrm{b}$ & $\mathrm{c}$ & $\mathrm{d}$ & $\mathrm{e}$ \\
\hline Grain Size (nm) & $43.3 \pm 0.6$ & $43.0 \pm 0.7$ & $34.7 \pm 0.6$ & $37.8 \pm 0.7$ & $38.2 \pm 0.8$ \\
\hline \hline
\end{tabular}

aligned (002) texture by the epitaxy-like growth. As the energy of the adatoms becomes lower due to the higher deposition pressure and shorter mean free path, the epitaxy-like growth becomes distorted, and the angular distribution among the grown (002) grains increases.

In Fig. 2(c), the carrier mobility values of the films were plotted in terms of $\mathrm{FWHM}_{2 \theta}$ and $\mathrm{FWHM}_{\omega}$. From the left graph of the mobility in terms of the $\mathrm{FWHM}_{2}$, we cannot find any consistent relationship between the mobility and the grain size estimated by the $\mathrm{FWHM}_{2 \theta}$ with the well-known Scherrer's equation [26]. Table I shows the vertical grain size estimated by the $\theta-2 \theta$ diffraction. On the other hand, the mobility in terms of the $\mathrm{FWHM}_{\omega}$ shows monotonic increase of the carrier mobility from 22.0 to $45.0 \mathrm{~cm}^{2} / \mathrm{V} \cdot \mathrm{s}$ as the $\mathrm{FWHM}_{\omega}$ reduces from $11.9^{\circ}$ to $2.7^{\circ}$. The angular distribution of (002) grains estimated by the $\mathrm{FWHM}_{\omega}$ can be associated with the Seto's carrier-transport model [27] that traps existed in the grain boundaries act as a barrier against the intergrain carrier transport. It is reasonable that the $\mathrm{ZnO}$ :Al films with less $\mathrm{FWHM}_{\omega}$ have lower angle grain boundaries, which gives less defects or traps, and thus lower energy barrier against the carrier transport yielding improved

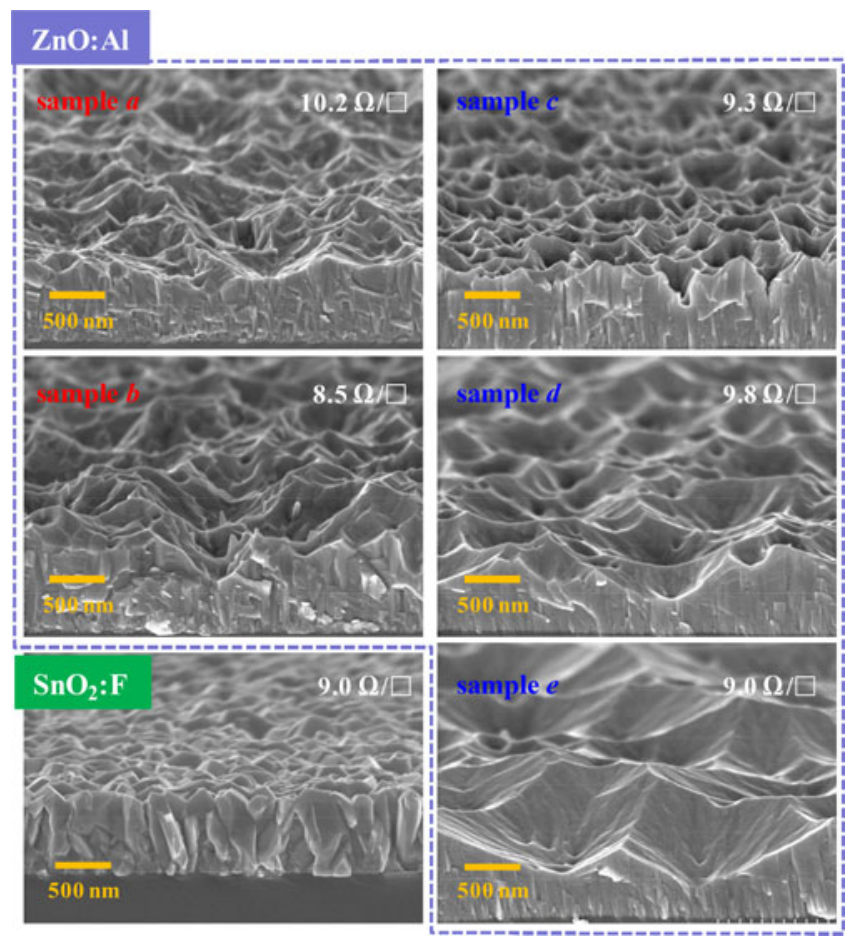

Fig. 3. SEM images of textured $\mathrm{ZnO}: \mathrm{Al}$ and $\mathrm{SnO}_{2}: \mathrm{F}$ substrates with sheetresistance values.

carrier mobility. Therefore, the reduced angular distribution of the (002) columnar grains can be the main origin for the improvement of the carrier mobility by the seed layer adoption.

\section{Textured Surface of $\mathrm{ZnO}$ :Al by Wet Etching}

Fig. 3 shows SEM images of the surface morphology of the etched $\mathrm{ZnO}: \mathrm{Al}$ and a commercial $\mathrm{SnO}_{2}: \mathrm{F}$-coated glass samples. There appeared many craters on the surface of the $\mathrm{ZnO}: \mathrm{Al}$ films, and the overall crater size increased as the deposition pressure decreased. The commercial $\mathrm{SnO}_{2}: \mathrm{F}$ film had no crater but had relatively small randomly distributed pyramids. For the light trapping of NIR wavelength which is very weakly absorbed by $\mu c-S i$ thin film [1], the rough surface dimension should be comparable with the wavelength, i.e., approximately $1 \mu \mathrm{m}$ or larger. Therefore, the $\mathrm{ZnO}$ :Al films can be more beneficial than the commercial $\mathrm{SnO}_{2}: \mathrm{F}$ substrate for the $\mu c$-Si thin-film solar cell.

Clear difference of the $\mathrm{ZnO}: \mathrm{Al}$ films with/without the seed layer is the microroughness of the inner crater surface. The wetetched $\mathrm{ZnO}$ :Al films $\boldsymbol{a}$ and $\boldsymbol{b}$ (without seed layer) had relatively rough inner surface in the craters, whereas the $\mathrm{ZnO}$ :Al films $\boldsymbol{c}-\boldsymbol{e}$ (grown on the seed layer) had relatively smooth inner surface in their etched craters. It is very important because the sharp valleys of the TCO substrate cause crack-like defects in the absorbing $\mathrm{Si}$ layers, causing decreased $V_{\text {oc }}$ and $F F$ [13], [14]. Owen et al. [28] showed that the vertically preferred (002) orientation is essential for the formation of the large craters with smooth inner surface in the polycrystalline $\mathrm{ZnO}$ films. Therefore, the existence of the vertical (101) grains without the seed layer [as shown in 


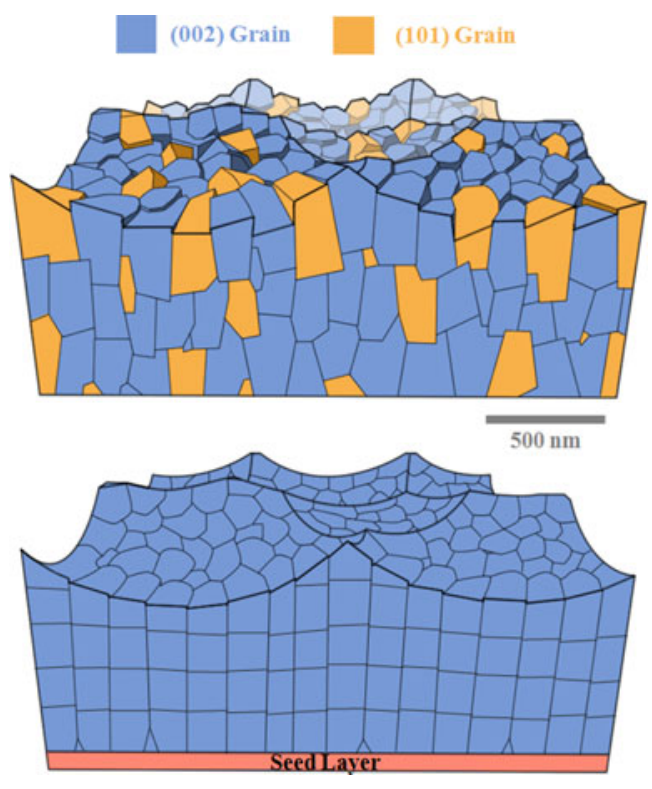

Fig. 4. Schematic for the different textured surface morphologies between the etched $\mathrm{ZnO}: \mathrm{Al}$ films, without a seed layer (upper), and those grown on a seed layer (lower). The $\mathrm{ZnO}$ :Al film without a seed layer has many irregularly fragmented (002) and (101) grains with roughnesses inside craters. In contrast, the film with a seed layer has well-oriented (002) grains with relatively smooth inner surface in each etched crater.

Fig. 2(a)] can be the origin of the microroughness evolution in the wet-etched craters.

Fig. 4 shows schematic images to explain the grain-structure evolution and its effects on the wet-etched $\mathrm{ZnO}$ :Al surface morphology. The upper image shows the $\mathrm{ZnO}: \mathrm{Al}$ film without seed layer, in which the (002) and (101) grains are coexisted. Because of the repetitive interruption during the film growth in the dynamic sputtering process without the initial (002) texture formation, the transition of the growth mode from the nucleationmerge stage into the epitaxy-like growth stage was delayed, and thus, (101) grains were able to survive during the thick film growth. The survived (101) planes near the surface caused the irregular postetched surface morphology in the craters. On the other hand, the films with (002) seed layer, in which epitaxy-like growth occurred in spite of the periodical growth interruption, (002) preferred orientation near the surface led to the $1-2-\mu \mathrm{m}-$ sized craters with smooth inner surface.

Optical haze and absorptance spectra of the textured TCO samples were measured as shown in Fig. 5. As expected from the wet-etched morphology from Fig. 3, the overall haze level increased as the deposition pressure decreased, irrespective of whether the seed layer was adopted or not. Remarkably, the haze levels of the samples that were deposited at the same pressure were similar irrespective of the existence of the seed layer. For example, the samples $\boldsymbol{a}$ and $\boldsymbol{c}$ (deposited at $0.5 \mathrm{~Pa}$ ) had similar haze levels ( $\boldsymbol{a}$ with the seed layer, while $\boldsymbol{c}$ without seed layer). The samples $\boldsymbol{b}$ and $\boldsymbol{d}$ were analogous. The absorptance of the $\mathrm{ZnO}$ :Al films [see Fig. 4(b)] can be considered as a criterion for the optical absorption loss by the front TCO in the thin-film solar cell. From samples $\boldsymbol{a}-\boldsymbol{e}$, the overall absorptance decreased. The improvement of the mobility resulted in the reduced free-carrier
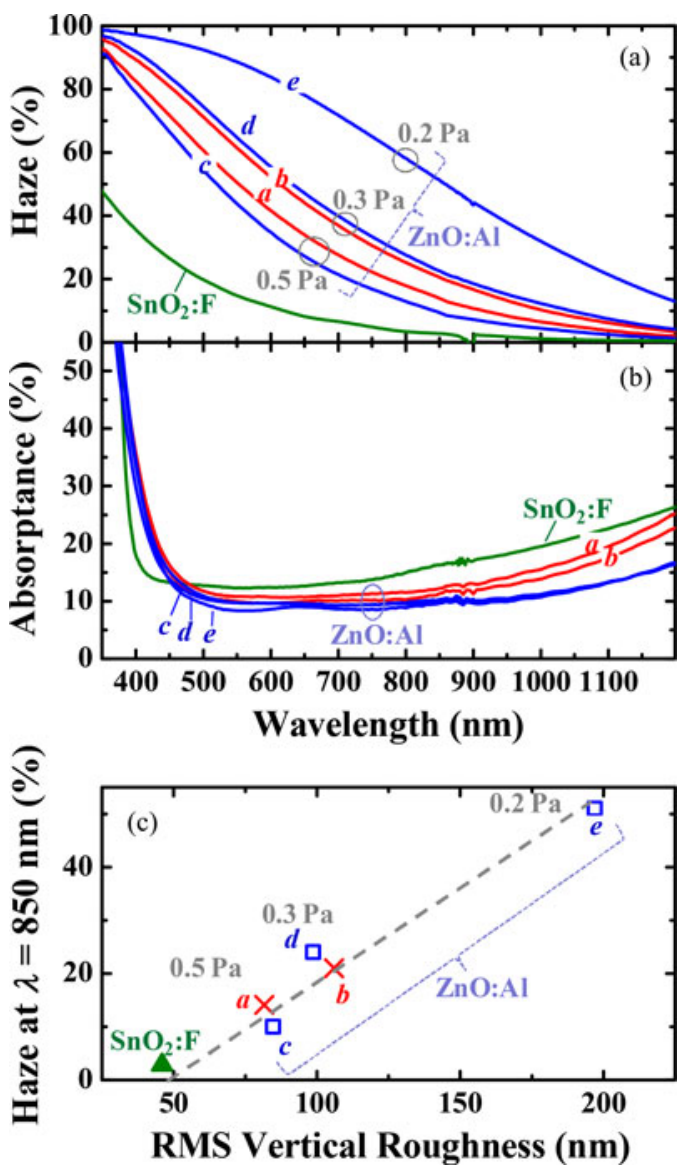

Fig. 5. (a) Optical haze and (b) absorptance spectra of the textured $\mathrm{ZnO}: \mathrm{Al}$ samples and commercial $\mathrm{SnO}_{2}: \mathrm{F}$ substrate. (c) Plots of haze (at $850 \mathrm{~nm}$ ) in terms of RMS vertical roughness of $\mathrm{ZnO}: \mathrm{Al}$ and $\mathrm{SnO}_{2}: \mathrm{F}$.

absorption and less film thickness with similar sheet resistance level.

\section{Solar Cell Results}

The microcrystalline $\mathrm{Si}(\mu c-\mathrm{Si}: \mathrm{H})$ thin-film solar cell was fabricated on the optimized $\mathrm{ZnO}: \mathrm{Al}$ substrate. For comparison, the commercial $\mathrm{SnO}_{2}$ :F-coated glass was also used as a front TCO contact. Fig. 6 shows the EQE of the two solar cells, with the open-circuit voltage $\left(V_{\text {oc }}\right)$, short-circuit current density $\left(J_{\mathrm{sc}}\right)$, fill factor $(F F)$, and the conversion efficiency $(\eta)$, extracted from the photocurrent-voltage $(J-V)$ curve of the solar cell. As expected from superior optical transparency and haze ratio of the in-house $\mathrm{ZnO}$ :Al substrate to those of commercial $\mathrm{SnO}_{2}: \mathrm{F}$ substrate (as shown in Fig. 5), the EQE of the solar cell grown on $\mathrm{ZnO}: \mathrm{Al}$ was larger than that of the $\mathrm{SnO}_{2}: \mathrm{F}$ substrate, especially in the wavelength range longer than $600 \mathrm{~nm}$. Additionally, the solar cell on the $\mathrm{ZnO}: \mathrm{Al}$ substrate had larger $V_{\text {oc }}$ and $F F$ values than that on the $\mathrm{SnO}_{2}: \mathrm{F}$ substrate, which resulted from the less shunt paths by the crack-like defects. From high $J_{\mathrm{sc}}$ of $26 \mathrm{~mA} / \mathrm{cm}^{2}$, and superior $V_{\text {oc }}$ and $F F$ compared with the cell grown on the $\mathrm{SnO}_{2}: \mathrm{F}$ substrate, we can predict that the $a$ $\mathrm{Si}: \mathrm{H} / \mu c$-Si:H double-junction tandem cell using the developed $\mathrm{ZnO}: \mathrm{Al}$ substrate by this research can potentially reach up to $\sim 13 \%$ conversion efficiency [5]. 


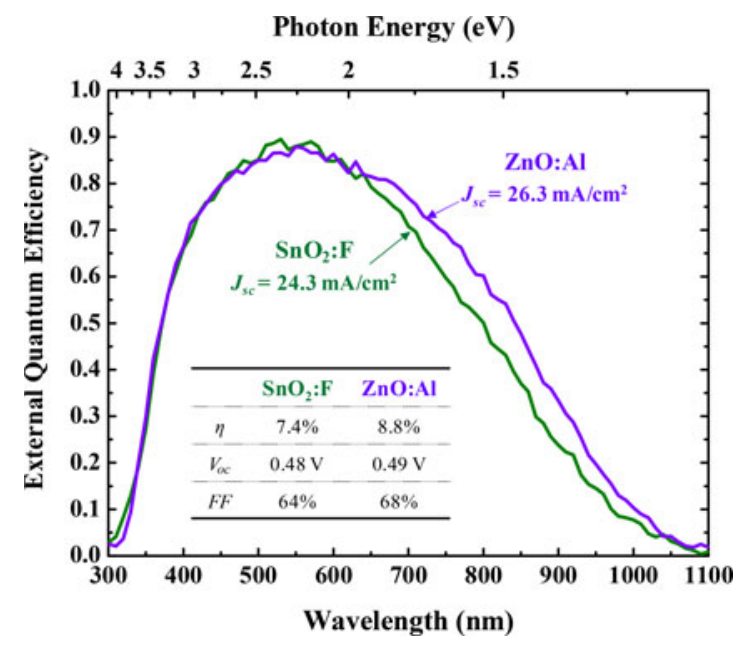

Fig. 6. Comparison of the $\mathrm{EQE}$ of the $\mu c$-Si:H thin-film solar cells made of commercial $\mathrm{SnO}_{2}: \mathrm{F}$ and in-house $\mathrm{ZnO}: \mathrm{Al}$ substrates with optimized process conditions. Light $J-V$ parameters of the solar cells are also compared.

\section{CONCLUSION}

The oxygen-controlled seed layer in the dynamic dc magnetron sputtered $\mathrm{ZnO}: \mathrm{Al}$ thin film, which is compatible with practical industrial processes, has resulted in the enhanced electrical mobility and appropriate etched morphology for Si thinfilm solar cells. Although it has been generally reported that deposition temperature higher than $350{ }^{\circ} \mathrm{C}$ is necessary for superior properties, $\mathrm{ZnO}: \mathrm{Al}$ film grown on the seed layer showed the carrier mobility of $45 \mathrm{~cm}^{2} / \mathrm{V} \cdot \mathrm{s}$, which approached the upper limit of the $\mathrm{ZnO}$-based material, even at the relatively low deposition temperature of $300{ }^{\circ} \mathrm{C}$. The main origin of the improved carrier mobility was found to be the reduced angular distribution of the vertically elongated (002) grains from $11.9^{\circ}$ to $2.7^{\circ}$, as confirmed by the diffraction rocking curve. It was further discussed that obtaining perfect (002) preferred orientation was important for the smooth crater surface of the wetetched $\mathrm{ZnO}: \mathrm{Al}$, which leads to a better performance of the $\mathrm{Si}$ thin-film solar cells. The $\mu c$-Si:H thin-film solar cell with the optimized ZnO:Al substrate showed high $J_{\mathrm{sc}}$ of $26.3 \mathrm{~mA} / \mathrm{cm}^{2}$, which means that $a$-Si:H/ $\mu c$-Si:H thin-film solar cells adopting this superior $\mathrm{ZnO}: \mathrm{Al}$ substrate can potentially reach $\sim 13 \%$ conversion efficiency.

\section{REFERENCES}

[1] J. Müller, B. Rech, J. Springer, and M. Vanecek, "TCO and light trapping in silicon thin film solar cells," Sol. Energy, vol. 77, pp. 917-930, 2004.

[2] M. Berginski, J. Hüpkes, M. Schulte, G. Schöpe, H. Stiebig, and B. Rech, "The effect of front $\mathrm{ZnO}: \mathrm{Al}$ surface texture and optical transparency on efficient light trapping in silicon thin-film solar cells," J. Appl. Phys., vol. 10, pp. 074903-1-074903-14, 2007.

[3] M. Zeman and J. Krc, "Electrical and optical modelling of thin-film silicon solar cells," in Proc. Mater. Res. Soc. Symp., 2008, vol. 989, pp. A03-A01.

[4] C. Rockstuhl, S. Fahr, K. Bittkau, T. Beckers, R. Carius, F.-J. Haug, T. Söderström, C. Ballif, and F. Lederer, "Comparison and optimization of randomly textured surfaces in thin-film solar cells," Opt. Exp., vol. 18, pp. A335-A342, 2010.
[5] S. Kim, J.-W. Chung, H. Lee, J. Park, Y. Heo, and H.-M. Lee, "Remarkable progress in thin-film silicon solar cells using high-efficiency triple-junction technology," Sol. Energy Mater. Sol. Cells, vol. 119, pp. 26-35, 2013.

[6] D. U. Kim, C. M. Hangarter, R. Debnatha, J. Y. Ha, C. R. Beauchampa M. D. Widstrom, J. E. Guyer, N. Nguyene, B. Y. Yoo, and D. Josell, "Backcontact CdSe/CdTe windowless solar cells," Sol. Energy Mater. Sol. Cells, vol. 109, pp. 246-253, 2013.

[7] H. Kim, M. Osofsky, S. M. Prokes, O. J. Glembocki, and A. Piqué, "Optimization of Al-doped $\mathrm{ZnO}$ films for low loss plasmonic materials at telecommunication wavelengths," Appl. Phys. Lett., vol. 102, pp. 1711031-171103-4, 2013.

[8] S.-Y. Lee, W. Lee, C. Nahm, J. Kim, S. Byun, T. Hwang, B.-K. Lee, Y. I. Jang, S. Lee, H.-M. Lee, and B. Park, "Nanostructural analysis of $\mathrm{ZnO}$ :Al thin films for carrier-transport mechanisms," Current Appl. Phys., vol. 13, pp. 775-778, 2013.

[9] C. Nahm, S. Shin, W. Lee, J. I. Kim, D.-R. Jung, J. Kim, S. Nam, S. Byun, and B. Park, "Electronic transport and carrier concentration in conductive ZnO:Ga thin films," Current Appl. Phys., vol. 13, pp. 415-418, 2013.

[10] H. Zhu, E. Bunte, J. Hüpkes, H. Siekmann, and S. M. Huang, "Aluminium doped zinc oxide sputtered from rotatable dual magnetrons for thin film silicon solar cells," Thin Solid Films, vol. 517, pp. 3161-3166, 2009.

[11] O. Kluth, G. Schöpe, J. Hüpkes, C. Agashe, J. Müller, and B. Rech, "Modified Thornton model for magnetron sputtered zinc oxide: Film structure and etching behavior," Thin Solid Films, vol. 442, pp. 80-85, 2003.

[12] S. J. Tark, M. G. Kang, S. Park, S. H. Lee, C.-S. Son, J. C. Lee, and D. Kim, "Characterization of hydrogenated Al-doped $\mathrm{ZnO}$ films prepared by multi-step texturing for photovoltaic applications," Current Appl. Phys., vol. 11, pp. 362-367, 2011.

[13] M. Python, O. Madani, D. Dominé, F. Meillaud, E. Vallat-Sauvain, and C Ballif, "Influence of the substrate geometrical parameters on microcrystalline silicon growth for thin-film solar cells," Sol. Energy Mater. Sol. Cells, vol. 93, pp. 1714-1720, 2009.

[14] H. B. T. Li, R. H. Franken, J. K. Rath, and R. E. I. Schropp, "Structural defects caused by a rough substrate and their influence on the performance of hydrogenated nano-crystalline silicon $n-i-p$ solar cells," Sol. Energy Mater. Sol. Cells, vol. 93, pp. 338-349, 2009.

[15] F. Ruske, A. Pflug, V. Sittinger, W. Werner, B. Szyszka, and D. J. Christie, "Reactive deposition of aluminum-doped zinc oxide thin films using high power pulsed magnetron sputtering," Thin Solid Films, vol. 516, pp. 4472-4477, 2008.

[16] J.-I. Nomoto, T. Hirano, T. Miyata, and T. Minami, "Preparation of Aldoped $\mathrm{ZnO}$ transparent electrodes suitable for thin-film solar cell applications by various types of magnetron sputtering depositions," Thin Solid Films, vol. 520, pp. 1400-1406, 2011.

[17] X. L. Chen, X. H. Geng, J. M. Xue, and L. N. Li, "Two-step growth of ZnO films with high conductivity and high roughness," J. Crystal Growth, vol. 299 , pp. 77-81, 2007.

[18] C. Y. Hsu, T. F. Ko, and Y. M. Huang, "Influence of $\mathrm{ZnO}$ buffer layer on AZO film properties by radio frequency magnetron sputtering," J. Eur. Ceramic Soc., vol. 28, pp. 3065-3070, 2008.

[19] W. Dewald, V. Sittinger, B. Szyszka, F. Säuberlich, B. Stannowski, D. Köhl, P. Ries, and M. Wuttig, "Advanced properties of Al-doped $\mathrm{ZnO}$ films with a seed layer approach for industrial thin film photovoltaic application," Thin Solid Films, vol. 534, vol. 474-481, 2013.

[20] T. Moon, W. Yoon, K. S. Ji, S.-W. Ahn, S. Lee, M. Joo, H. Y. Shin, K. Park, and H.-M. Lee, "Microstructure and light-scattering properties of $\mathrm{ZnO}: \mathrm{Al}$ films prepared using a two-step process through the control of oxygen pressure," Appl. Phys. Exp., vol. 3, pp. 095801-1-095801-3, 2010.

[21] G. E. Jellison, Jr., and F. A. Modine, "Parameterization of the optical functions of amorphous materials in the interband region," Appl. Phys. Lett., vol. 69, pp. 371-374, 1996.

[22] S. Kim, J. Park, H. Lee, H. Lee, S.-W. Ahn, and H.-M. Lee, "Microcrystalline silicon carbide p-layer with wide-bandgap and its application to single- and triple-junction silicon thin-film solar cells," Jpn. J. Appl. Phys., vol. 51, pp. 10NB11-1-10NB11-3, 2012.

[23] K. Ellmer, "Resistivity of polycrystalline zinc oxide films: Current status and physical limit," J. Phys. D, Appl. Phys., vol. 34, pp. 3097-3108, 2001.

[24] F. Ruske, C. Jacobs, V. Sittinger, B. Szyszka, and W. Werner, "Large area $\mathrm{ZnO}: \mathrm{Al}$ films with tailored light scattering properties for photovoltaic applications," Thin Solid Films, vol. 515, pp. 8695-8698, 2007.

[25] D. Köhl, "The influence of energetic bombardment on the structure formation of sputtered zinc oxide films-Development of an atomistic model and its application to tailor thin film properties," Ph.D. dissertation, RWTH Aachen, Aachen, Germany, 2011. 
[26] P. Scherrer, "Bestimmung der Grösse und der inneren Struktur von Kolloidteilchen mittels Röntgenstrahlen," Nachr. Ges. Wiss. Göttingen, vol. 26, pp. 98-100, 1918.

[27] J. Y. Seto, "The electrical properties of polycrystalline silicon films," $J$. Appl. Phys., vol. 46, pp. 5247-5254, 1975.

[28] J. I. Owen, W. Zhang, D. Köhl, and J. Hüpkes, "Study on the in-line sputtering growth and structural properties of polycrystalline $\mathrm{ZnO}: \mathrm{Al}$ on ZnO and glass," J. Crystal Growth, vol. 344, pp. 12-18, 2005.

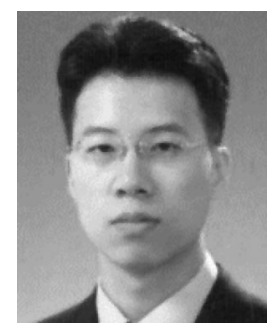

Seung-Yoon Lee is currently working toward the $\mathrm{Ph} . \mathrm{D}$. degree in materials science and engineering with Seoul National University, Seoul, Korea.

Since 2003, he has been with LG Advanced Research Institute as a Senior (up to 2010) and a Chief (since 2011) Research Engineer. His research interests include the process development of semiconductor, dielectric, and transparent conductive oxide thin films and their applications to high-efficiency solar cells.

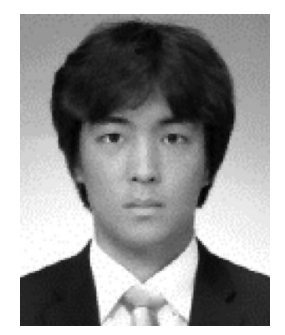

Taehyun Hwang is currently working toward the $\mathrm{Ph} . \mathrm{D}$. degree in materials science and engineering with Seoul National University, Seoul, Korea.

His current research interests include the fabrication of nanoporous materials and perovskite solar cells.

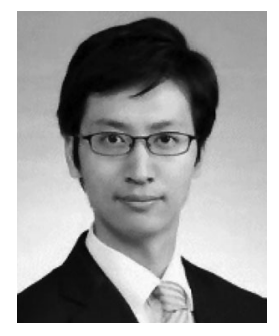

Woojin Lee is currently working toward the Ph.D. degree in materials science and engineering with Seoul National University, Seoul, Korea.

His research interests include nanomaterials, solar energy conversion, and transparent conducting oxides.

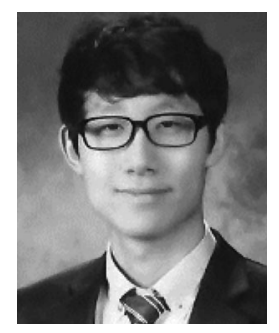

Sangheon Lee is currently working toward the Ph.D degree in materials science and engineering with Seoul National University, Seoul, Korea.

His current research interests include the design of metal-oxide-based porous photoanodes for semiconductor sensitized solar cells.

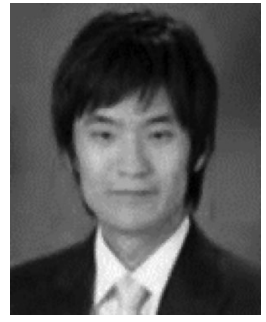

Hongsik Choi received the Ph.D. degree in materials science and engineering from Seoul National University, Seoul, Korea, in 2014.

His main research interests include the development of nanoscale coatings for sensitized solar cells.

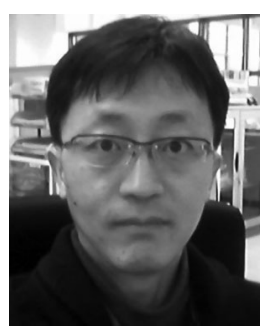

Seh-Won Ahn received the Ph.D. degree in electrical engineering from the Korea Advanced Institute of Science and Technology, Daejeon, Korea, in 2001.

Since 2006, he has been involved in the development of Si thin-film solar cells with the LG Electronics Advanced Research Institute, Seoul, Korea, where he is leading a project for the development of high-efficiency crystalline $\mathrm{Si}$ solar cells.

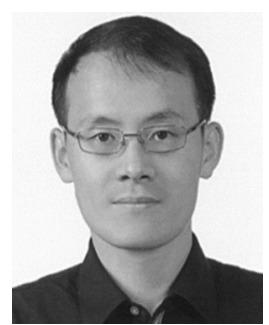

Heon-Min Lee received the Ph.D. degree in electrical engineering and computer science from the Korea Advanced Institute of Science and Technology, Daejeon, Korea, in 2005.

He is currently a Solar Energy Team Leader with LG Electronics Advanced Research Institute, Seoul, Korea, leading several projects, such as the development of III-V compound semiconductor solar cells, crystalline Si solar cells, and amorphous Si-based triple-junction solar cells.

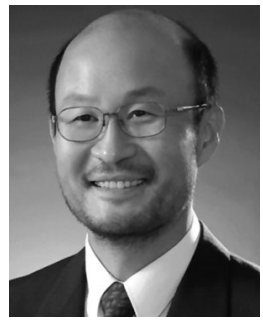

Byungwoo Park received the Ph.D. degree in applied physics from Harvard University, Cambridge, MA, USA, in 1989.

He has been with the IBM T. J. Watson Research Center, California Institute of Technology, and Georgia Institute of Technology. He has been a Professor with the Department of Materials Science and Engineering, Seoul National University, Seoul, Korea, since 1997. His current research interests include the development of nanoscale coating, novel nanocomposites, quantum-dot sensitized solar cells, nanophase control of thin-film electrodes, and the growth kinetics of nanostructures. 